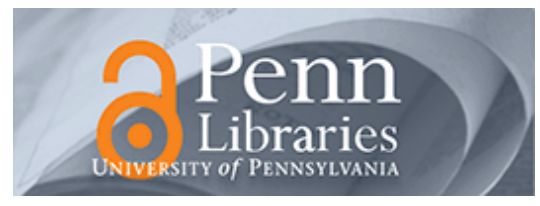

University of Pennsylvania ScholarlyCommons

$1-1-2003$

\title{
A Renaissance on the Eastside: Motivating Inner-City Youth Through Art
}

MaryBeth Gasman

University of Pennsylvania, mgasman@gse.upenn.edu

Sibby Anderson-Thompkins

Georgia State University

Follow this and additional works at: https://repository.upenn.edu/gse_pubs

Part of the Bilingual, Multilingual, and Multicultural Education Commons

\section{Recommended Citation}

Gasman, M., \& Anderson-Thompkins, S. (2003). A Renaissance on the Eastside: Motivating Inner-City Youth Through Art. Retrieved from https://repository.upenn.edu/gse_pubs/20

Reprinted from Journal of Education for Students Placed at Risk, Volume 8, Issue 4, 2003, pages 429-450. Publisher URL: http://www.erlbaum.com/Journals/journals/JESPAR/jespar.htm

This paper is posted at ScholarlyCommons. https://repository.upenn.edu/gse_pubs/20

For more information, please contact repository@pobox.upenn.edu. 


\title{
A Renaissance on the Eastside: Motivating Inner-City Youth Through Art
}

\author{
Abstract \\ Research tells us that children are more susceptible to temptations between the hours of 2:00 p.m. and \\ 6:00 p.m. - the hours following the end of the school day when parents are not yet home from work. This \\ study looks at the "life histories" of child participants in the Artists in the Making (AIM) program-a \\ program that aims to motivate inner-city youth through the use of visual arts classes. Despite the diversity \\ of the children who participated in the AIM program, several common themes emerged from the interview \\ process: self-discovery, problem-solving skills, opportunities for positive risk taking, and the mastery of \\ artistic skills. This article proposes that community-based visual arts programs can help children develop \\ protective factors that will allow them to be resilient. \\ When I draw, I feel like I am in another world. When I go home after class, I feel like I am walking back into \\ hell. ("Rashie," a student in the Artists in the Making program, 1998).

\section{Disciplines} \\ Bilingual, Multilingual, and Multicultural Education

\section{Comments} \\ Reprinted from Journal of Education for Students Placed at Risk, Volume 8, Issue 4, 2003, pages 429-450. \\ Publisher URL: http://www.erlbaum.com/Journals/journals/JESPAR/jespar.htm
}




\title{
A Renaissance on the Eastside: Motivating Inner-City Youth Through Art
}

\author{
Marybeth Gasman \\ Graduate School of Education \\ University of Pennsylvania \\ Sibby Anderson-Thompkins \\ Educational Policy Studies \\ Georgia State University
}

\begin{abstract}
Research tells us that children are more susceptible to temptations between the hours of 2:00 p.m. and 6:00 p.m. - the hours following the end of the school day when parents are not yet home from work. This study looks at the "life histories" of child participants in the Artists in the Making (AIM) program-a program that aims to motivate inner-city youth through the use of visual arts classes. Despite the diversity of the children who participated in the AIM program, several common themes emerged from the interview process: self-discovery, problem-solving skills, opportunities for positive risk taking, and the mastery of artistic skills. This article proposes that community-based visual arts programs can help children develop protective factors that will allow them to be resilient.
\end{abstract}

When I draw, I feel like I am in another world. When I go home after class, I feel like I am walking back into hell. ("Rashie," a student in the Artists in the Making program, 1998)

According to the FBI's National Incident-Based Reporting System, "One in five violent crimes committed by juveniles occur in the four hours following the end of the school day-between 2:00 p.m. and 6:00 p.m." (Department of Justice, 2001;

Requests for reprints should be sent to Marybeth Gasman, Assistant Professor, Higher Education, Graduate School of Education, University of Pennsylvania, 3700 Walnut Street, Philidelphia, PA 19104-6216. 
National Commission on Children, 1993; Task Force on Youth Development and Community Programs, 1992). A 1992 Carnegie Report expanded on this statistic:

Some [children] injure their health by using tobacco, alcohol, and other drugs. Some engage in premature, unprotected sexual activity, which the presence of AIDS now renders deadly. Some commit acts of crime or live in neighborhoods where fear of violence pervades their daily lives. Although all adolescents face at least some of these hazards, those who live in urban and rural poverty areas face a higher level of risk. These outcomes can be reversed, if Americans decide to create communities that ... provide opportunities for them during the nonschool hours. (Carnegie Council on Adolescent Development, 1992, pp. 9-10)

Many parents, teachers, community leaders, and citizens search for ways to counteract this problem. How can we make a change and create venues for children that stimulate their creativity and thinking and thus reduce their propensity to participate in disruptive activities? One approach is through art. Heath and Roach (1998) found that "art programs encourage discussion and dialog between teachers and students regardless of age, set the stage for regular self-expression, increase a child's self-image, and reduce a child's delinquent behavior" (p. 20). Inspired by Heath and Roach's findings, the staff at the Ella Austin Community Center created a program entitled Artists in the Making (AIM). ${ }^{1}$

\section{RELEVANT LITERATURE}

Throughout the literature on youth development, researchers suggest that effective after-school programs can have a dramatic impact on reducing the risk factors that contribute to drug and substance abuse, gang activity, teen pregnancy, violence, and juvenile delinquency among youth (Americans for the Arts, 1998; Becker, 1994; Costello, 1995; Fiske, 1999; Hawkins \& Catalano, 1993; Heath \& McLaughlin, 1993; Lakes, 1996; McLaughlin, Irby, \& Langman, 1994; Mortimer, 1994; Randall, 1997; Schorr, 1989; Weitz, 1996). One strategy put forth for reducing risk factors is community-based arts initiatives. The previously mentioned research indicates that these initiatives provide a positive alternative for youth during nonschool hours that allows participants to develop protective factors such as caring relationships with adults, the ability to resist negative peer pressures, and the opportunity to build positive self-esteem while fostering resiliency.

In a report issued by Creative Partnerships for Prevention (1998), resiliency is defined as "an ability to successfully adapt and develop in healthy ways, despite

\footnotetext{
${ }^{1}$ The Heath and Roach (1998) study was cited in the Ella Austin Community Center's original grant proposal. It was used to discuss the after-school hours and the behaviors resulting from a lack of planned activity for youth.
} 
exposure to risk or difficulty" (p. 5). According to the literature, resilient youth are better able than their nonresilient counterparts to build healthy relationships or to negotiate conflicts or disputes successfully (Baxley, 1993; Bernard, 1992; Carnegie Council on Adolescent Development, 1992). In addition, resilient youth possess a strong sense of independence that allows them to see themselves as autonomous from their troubled environments. Moreover, resilient youth believe that they can practice personal power or control in their lives.

\section{FOSTERING RESILIENCY THROUGH THE ARTS}

Several studies suggest that effective community-based arts programs share common characteristics. Fiske (1999), Heath and Roach (1999), Otterbourg (2000), and Witt (1997) found that community-based arts programs enabled youth to have direct involvement with artists. According to Heath and Roach (1998), "the strong benefit that young students receive from the instruction and interaction of arts education programs is the promotion of natural language patterns that seek information, opinion, reflection, and critical comments." Further, youth in art programs "engage in regular oral exchanges with older peers and adults around problem posing and hypothetical reasoning" (Heath \& Roach, 1998, pp. 2-3). In addition, these programs take a hands-on approach, engaging youth directly in the artistic process. Baxley (1993) suggested that the positive effects of hands-on creative work may be due to youth having the opportunity to practice positive risk taking. Unlike conventional learning settings—such as school, where the goal is to produce the right answer-hands-on creative work allows young people a chance to experiment with multiple artistic methods and to explore different outcomes without the risk of failure.

Another common characteristic of successful arts programs is that they help young people build social competence and effective problem-solving skills (e.g., cooperation, communication). Research suggests that youth who participate in community-based arts initiatives express having greater tolerance and respect for difference. They also develop coping strategies that enable them to better handle conflict. In fact, the 1998 Creative Partnerships for Prevention report suggested that "the arts and humanities can be powerful conflict resolution tools, helping students understand, appreciate and adapt to others' ways of thinking, working and expressing themselves" (p. 15). Similarly, Fiske (1999) found that youth participating in programs reported that the arts challenged them to not "oversimplify" problems but to examine obstacles from multiple dimensions, whereas Clawson and Coolbaugh (2001) found that youth involved in the arts developed skills in "expressing anger appropriately, communicating effectively with adults and peers, [and] cooperating with others" (p. 2). 
For youth coping with anger and frustration, art has the capacity to offer a positive alternative to destructive behavior. In an interview with Vince Sehle (1995), William Strickland contended that art

is a way of saving kids' lives, oftentimes quite literally. This [art] is an alternative to dying for a lot of these kids. They don't see anything like this in their lives, in school, or in the communities where they live. Where people say you're something. (p. 6)

In addition, for many of these kids who live in the poorest areas, art serves as a deterrent- "discouraging kids from getting addicted to drugs and instead getting kids addicted to living" (p. 6).

Research suggests that involvement in the arts helps youth, who otherwise would not have such an opportunity, to develop relationships with artists and other caring adults who express high expectations for them (Clawson \& Coolbaugh, 2001; Heath \& Roach, 1999). The Creative Partnerships for Prevention (1998) report contended that "the presence of a genuinely interested individual who can serve as a mentor is sometimes the defining factor in a young person's life-from risk to resiliency" (p. 12). Research also suggests improved relationships among peers. For instance, Witt (1997) asserted that youth involved with art reported "enhanced feelings of belonging" (p. 21). Likewise, Horowitz (1980) found that using creative photography with inner-city youth helped participants to gain self-confidence through the mastery of basic photography skills; build honest, trusting relationships with peers; and experience a supportive environment for feedback on how others saw them. In addition, the program offered participants a safe space to do what is often characterized as "unacceptable in other settings"- express themselves and speak freely about their feelings.

Effective community-based programs also foster positive self-esteem and self-identity in youth (Catalano, Loeber, \& McKinney, 1999; Clawson \& Coolbaugh, 2001; Fiske, 1999). Heath and Roach (1999) found that participation in the arts improved students' perceptions of self. In fact, students reported that they felt good about themselves; had more personal worth; were capable of doing things as well as others; and, on the whole, were satisfied with themselves. Likewise, London (1994) contended that making art offers youth a self-discovery process-a way to discover the world and to discover themselves. London believed that through the use of arts, young people are encouraged to challenge traditional notions of beauty. According to London, art offers the ability to create images that reflect different ideas of beauty, allows students to foster positive self-concepts, and has the potential to diminish the harmful effects of racism and sexism.

Moreover, research suggests that effective arts programs address the particular challenges facing youth of color in achieving a positive self-identity. These programs recognize that for many youth of color, their experiences in other learning settings such as school have been shaped by invisibility or the lack of positive cultural 
representations. Effective arts programs address issues related to a student's particular race, ethnicity, and gender identity (Creative Partnerships for Prevention, 1998).

The most effective arts programs take a comprehensive and holistic approach to working with young people. Clawson and Coolbaugh (2001), Creative Partnerships for Prevention (1998), Fiske (1999), and Otterbourg (2000) consistently found that programs offering services and workshops to address a wide range of issues including drug and substance abuse, pregnancy prevention, and mentoring needs were most effective. Research suggests these programs were successful because they took an integrated approach in addressing the needs of youth while providing a range of resources and services (Clawson \& Coolbaugh, 2001; Fiske, 1999; Otterbourg, 2000).

However, the single most important characteristic in effective programs is the involvement of young people's parents, community members, and schools. Clawson and Coolbaugh (2001), Fiske (1999), and Otterbourg (2000) indicated that arts offered important connections between students' home and school lives and contributed to their overall personal growth and development. Similarly, Oreck, Baum, and McCartney (1999) found that "the type and level of parental support for the students' artistic development contradicts many common stereotypes about the lack of involvement on the part of economically disadvantaged, single working parents" (p. 77). In fact, they found that parental involvement and family support were critical factors in students' success in the arts.

In summary, the positive effects of art for youth are well documented. For many youth, community-based arts programs help to foster protective factors such as forging caring relationships with adults, resisting negative peer pressure, and building positive self-esteem while fostering resiliency. Art programs offer students opportunities to experience success and recognition for their accomplishments, and provide young people with occasions for active learning and direct participation in skill-building activities. In addition, the arts and humanities "offer creative and engaging ways to explore difficult, complex issues with youth" (Creative Partnerships for Prevention, 1998, p. 5).

\section{RESEARCH DESIGN AND METHODOLOGY}

According to John Dewey (Jackson, 1998), what we look forward to when doing art is the thrill of the experience and the process of doing art - the work of art is not the object but the experience (Dewey, 1934). Although one of the main goals of the AIM program was the production of art to be displayed in the community, this study focuses on the students' experiences as described by them. The experiences of the children are represented by the "life histories" of 4 children in the program. These life histories include the students' experiences in the AIM program, at school, and at home. The life histories focus on the children's interpretation and 
understanding of the world around them (Denzin \& Lincoln, 2000). The experiences of the 4 children presented in this article are representative of the prevailing themes found in the larger group of 40 AIM participant interviews. These themes include self-esteem or self-image, relationships with adults, ability to cope with anger, and ability to respond to peer pressure.

Although the life histories illuminate the experiences of the children with respect to the previously mentioned themes, we are not claiming direct correlation between the AIM program and improvements in these areas. The children highlighted in this article include "Jesse," a 12-year-old Mexican American girl; "Jonathan," an 11-year-old African American boy; "Rashie," a 12-year-old African American boy; and "Sheilay," a 12-year-old African American girl.

This study used a qualitative approach that included 1-hr, open-ended interviews with each of the children who participated in the AIM program. The same 10 questions were asked during each interview. Interviews were conducted twice per session during the course of the six sessions that took place over a 2-year period. Bridged by transitional moments, the interview questions were loosely phrased in the following way:

1. Why are you interested in art? Why are you participating in the program?

2. In addition to art, what other interests do you have? What do you do after school when you are not at art class?

3. What have you gained from participating in the AIM program?

4. How would you describe yourself?

5. Do you like other kids at school? Do they like you?

6. If another kid at school or after school makes you angry, what do you do?

7. Do you feel tempted to use drugs or drink alcohol?

8. How do you respond to temptation?

9. When you think about the future, what do you see?

10. What do you want to be when you grow up? Why?

To allow the children to explore their own ideas and areas of personal significance, all of the interviews were concluded with a short open-ended discussion that centered on the child's interests and concerns (Patton, 1980). Detailed notes were taken during each interview. Because of the nature of the interviews, the children's comfort level, and the possible legal implications, tape recorders were not used. The quotes contained in this article are all from the interviews. We wrote summary notes immediately following each interview in which we recorded the participant's reactions and comments and our preliminary thoughts on the emerging themes (Miles \& Huberman, 1984). In addition to the structured interviews, we engaged in participatory observation. This allowed us to observe the children in the art classroom throughout the week, and it created a sense of comfort for the children when the interviews began. 
As the data were collected, the common themes, salient issues, and concerns for future research were compared, coded, and analyzed according to methods suggested by Lincoln and Guba (1985). We considered what the children said (i.e., their words and language) and what was unsaid (i.e., body language and long pauses). Recognizing that dependability, transferability, credibility, and confirmability are important criteria for trustworthiness in qualitative research, we used multiple methods of data collection. For the purposes of this article, we focus on the interviews and participatory observation. However, the larger study included teacher observations and teacher reports, which were completed twice per session. These results will be reported in subsequent publications.

\section{SETTING}

The AIM program took place at the Ella Austin Community Center, which is located on the east side of the city of San Antonio, Texas. An economically depressed area, the East Side consisted mainly of African American and Mexican American families. Most families lived at or below the poverty level. The schools in the local area surrounding the center received Title I funds and their students all qualified for free lunches (San Antonio Public Schools, 2001). The neighborhood was beset by high crime rates and frequent gang activity and received little interest from the city's business community (City of San Antonio, 2000; A. E. Hargrove, personal communication, April 21, 2000).

In response to these problems, the Ella Austin Community Center offered services that ranged from early child development to senior citizen care. The families in the community knew that they could come to the center for food, help with electricity payments, literacy education, tax preparation assistance, nursing care, mentoring, and children's activities (Ella Austin Community Center, 1999-2000; L. J. Pantoja, personal communication, February 5, 2000). The center staff considered their efforts to be a grassroots attempt to counteract the negative forces in the local community with positive intervention (A. E. Hargrove, personal communication, April 21, 2000).

One of the many programs offered by the Ella Austin Community Center, the AIM program was a visual arts program. The goals of the program were to improve self-esteem, to provide an alternative to juvenile delinquency, to tap the talent that lay dormant in the children, to bolster the artistic skills that the children possessed, to encourage local artists to share their skills with the community, and to stimulate an increased interest in art among patrons of the community center and in the local East Side neighborhood.

The AIM program enrolled 40 students over a 2-year period of six sessions. Sessions were approximately $3 \frac{1}{2}$ months long. To situate the program at the end of the school day as prescribed by the literature, classes were held Monday through 
Friday from 3:00 p.m. until 6:30 p.m. (Carnegie Council on Adolescent Development, 1992; Department of Justice, 2001). With each session, the teachers and class content changed. Students were offered painting, drawing, mixed media, and sculpture as course options. Students completed an application to participate in AIM, which included short answer questions and a parental permission slip. Over the course of 2 years, 32 children consistently attended the program. Eight students dropped out of the program and were replaced by students on a waiting list. One of the major tenets of AIM was to put the children in an apprentice-like situation in which they would be learning from practicing artists. Therefore, small classes were essential to the program.

The students worked on projects that extended from class to class. They worked in groups of 10 under the guidance of a local artist. Artists and teachers had master's degrees in fine arts and were practicing artists in the local community. Artists made an application to teach in the program and were required to submit slides, a curriculum plan, a studio budget, and three references. An advisory committee composed of artists, gallery owners, community members, and art professors chose four artists for each session. Each artist was given a stipend of $\$ 2,500$ to be used during the $3 \frac{1}{2}$-month session.

With the exception of maintaining student interest in the art project at hand, the AIM staff handled all disciplinary issues. The artists did not have responsibility for any disciplinary action. Students were expected to avoid the use of profanity, to clean up their work area, to show respect for others' creative work and processes, and to show respect toward their peers and teachers. Most behavioral issues pertained to violating these group norms, which were established at the outset of the class. Students who violated the group norms were asked to leave the program for 1 day or a temporary period. If the behavior persisted, it was the policy to ask the student to leave the program for the duration of the session. During the entire time the program was under evaluation, only one student was asked to leave. ${ }^{2}$ She destroyed another student's art.

\section{THE USUAL ROUTINE}

On any given day, the students arrived at the AIM classroom shortly after school ended. The classroom environment was set up to reinforce the values of respect and personal responsibility. Students put on their aprons, pulled out their supply boxes, and sat at the table to begin a new project or continue an existing project. They were responsible for cleaning their work area, washing their brushes, picking up trash, putting away their supplies, and displaying their artwork in the class-

\footnotetext{
${ }^{2}$ Despite the use of the past tense in this description, the Artists in the Making program is still in operation at the Ella Austin Community Center.
} 
room. The value of the materials and importance of using them wisely was relayed to the students during the first class. They were taught to respect the materials, the workspace, other students, and their teachers. These ideas were conveyed initially by the AIM staff and by each instructor during the course of his or her teaching.

Near the completion of the session, the students and teachers worked together to choose artwork that would be displayed at a local museum. Because this event was the coming together of child, family, and community to share in the visual end-product, it was the pinnacle of the AIM experience. Of the exhibitions, one patron said, "What a great opportunity to encourage young artists as they discover who they are-as they explore both what's locked within and what's waiting to be released. Keep encouraging their talents and their spirit" (Anonymous museum patron, personal communication, August 10,1999). With the student's permission, the artwork was sold to the general public during exhibitions. All funds secured from the sale of a student's artwork were placed in a scholarship fund under his or her name until graduation from high school. At that point, the students were given the funds and any accrued interest to be used toward their college tuition and books.

The AIM program benefitted from a nexus of support, which included parents, schools, the East Side community, members of the art world, foundations, the business community, and the child (Creative Partnerships for Prevention, 1998; Fiske, 1999; Otterbourg, 2000). The parents of the children in AIM were required to make a significant commitment of time and effort to the program. Notably, they had to provide transportation to and from the program for their children, and most important, they were asked to motivate and encourage the artistic talent in their children. The schools on the east side of San Antonio played an integral role in the success of AIM by assisting with the application process and allowing the AIM staff access to the children in the school setting during the recruitment process. The East Side community came together to support the AIM students through attendance at end-of-session exhibitions and by visiting the art studio throughout the week.

One of the most important components of this project was the involvement of the local art community. Students benefitted from tours of galleries, museums, and artists' studios. They were exposed to new ideas, a diversity of artwork, and formerly "hidden" artistic aspects of the city. A critical factor here was the location of the exhibitions. It was essential to show work in high profile, prestigious venues so as to attract visitors, the media, and funders (Clawson \& Coolbaugh, 2001). Art exhibition space was provided at the San Antonio Museum of Art, the McNay Art Museum, and the ArtPace Foundation galleries.

Local and national foundations, as well as the city of San Antonio, provided the majority of the financial support for AIM. Not only did this defray expenses for the Ella Austin Community Center, but it also lent prestige and acted as an impetus for further giving to the center as a whole (A. E. Hargrove, personal communication, April 21, 2000). Also providing financial backing to the AIM program were local and national corporations that hold the arts in high regard. This support manifested 
itself in two forms: monetary contributions and gifts in kind (e.g., the receptions at exhibitions were sponsored by local supermarket chains, and a local printing company sponsored the exhibition announcements). However, the most significant participants were the children. They were expected to be not only hardworking and dedicated participants but also positive contributors to the classroom environment in the AIM studio. As in other successful programs for inner-city youth, the staff and teachers at AIM held high expectations for the students (Catalano et al., 1999; Clawson \& Coolbaugh, 2001; Heath \& Roach, 1999). However, these expectations were attainable through hard work on the part of the children and care and the provision of resources on the part of the teachers. According to Asa G. Hilliard (personal communication, September 14, 2001), a well-known educational researcher and psychologist, if expectations are held high for so-called at-risk students, they will meet these expectations if given attention, love, and resources.

\section{Findings: The Life Histories}

Despite the diversity of the children who participated in the AIM program, several common themes emerged from the interview process. These themes are represented by the life histories of four of the AIM children. An examination of the life histories will contribute to the literature by examining how protective factors in visual arts programs help inner-city youth build resiliency.

\section{JESSE}

Jesse, a 12-year-old Mexican American girl, lives with both of her parents in a small house several miles from the center. She has an older brother who "acts cool" and is "really good at art," as well as an older sister and a younger sister. Jesse's parents are second-generation immigrants. She is fluent in English and Spanish and is an excellent student in school where she participates in the American history magnet program. Jesse joined the AIM program because her older brother did. However, he dropped out of the program after 2 weeks to play soccer. At home, Jesse "helps [her] mom by doing chores around the house when [she] comes home from school. [She] feeds the dog, cleans up the kitchen and [her] room. [She] also does the ironing for the whole family."

When asked if and what she has gained from participating in the AIM program, Jesse said, "At school, I am in art class but we hardly do much art because we don't have enough supplies. I always show my friends what I learn at AIM. I get a lot of praise from them because of my skills. I like that." At the onset of the AIM program, Jesse told the teachers that she "hated her looks" and noted in her interview, "I don't like the way I look. People always tell me that I am not Mexican because my skin is too light. They make fun of me and I don't like it. I know that I am Mexi- 
can. I wish my skin were darker." Many of the girls had similar feelings to Jesse's. Therefore, the teachers started to talk about notions of beauty and how beauty is depicted in art. Considerable time was spent with the boys and girls in painting, drawing, and sculpting their ideas of beauty. During the concluding interview, Jesse was asked again, "How would you describe yourself?":

I am like coffee. I wake people up! I used to hate it when people thought I was White but now I have more self-confidence. I don't care what other people think about me. I am not foolish like some other teenagers. I try to think before I speak. My artistic talent is what I like best about myself.

A piece done by Jesse, entitled "Mexicana Girl," deals with the issue of ethnic pride. In it she depicts herself side-by-side with symbols from her culture-an angel and a devil-like figure (see Appendix A).

Jesse is popular at school among her friends, and in the AIM classroom she is seen as a leader. She and her friends at school occasionally run into trouble with other girls, especially those girls who participate in gangs. Of this experience, Jesse said,

I like everyone at school except a gang named the Midnight Colors or the MC's. They don't like me because they don't like my best friend and because I have self-respect. I don't like gangs because my sister had a boyfriend who was in a gang-when she broke up with him he tried to stalk her. Most kids probably think I'm conceited but I like who I am and I don't do what other people want me to do. I don't let people boss me around. I can think for myself.

Jesse's self-identified improvement in confidence has helped her when others have tried to tempt her with drugs or alcohol. She said,

I have been tempted. I have never tried anything. My grandfather has lung problems from smoking and alcohol messes up your head. I tell kids no and walk away. If my friends try to persuade me, I will tell their parents. I have told the parents of my friends before and my friends got mad.

In her concluding interview, Jesse proclaimed vehemently,

Kids who use alcohol and drugs don't have self-confidence. They may think it's cool to be a follower-but it's not. There is only one good reason to use drugs-if you are sick and a doctor gives them to you.

Jesse's improved self-confidence is also evident in her response to questions pertaining to anger management. When first asked how she dealt with confrontational 
situations she said, "Sometimes I get mad and want to hit someone but then I think about the consequences. I'd rather discuss things but I can back up my words if I need to." Based on comments like Jesse's that surfaced during the initial interviews, the teachers spent a considerable amount of time addressing issues of anger. The students talked about what made them angry, and teachers asked them to depict their feelings. Appendix B exemplifies the type of response the students produced. It is an abstract piece entitled "Fear." It depicts the fear that rests in the belly of a child.

During her concluding interview, Jesse responded to the same questions pertaining to anger with, "I walk away from kids who make me angry. I must walk away from angry situations otherwise things get out of control and people get hurt.” Jesse has recently graduated from the AIM program. She is now attending high school and participates in an art program geared toward older students. Of her future she says, "I will be a good person. I want to live in a big apartment with a backyard to plant flowers. I will go to college, have my own art studio, and I will be happy knowing I made it."

\section{RASHIE}

Rashie is a 12-year-old African American boy who lives in a run-down home near the center with his mother and his stepfather. He is very close to his mom and little sister and talks about his love for them during most interactions with teachers and staff at the AIM program. In fact, Rashie joined AIM because his mom wanted to encourage his love for art. According to the teachers, he has an amazing artistic ability and the potential to be a successful artist. However, when complimented by the teachers and other children, he acts surprised and downplays their compliments: "I am just doing my thing. This is nothing special, just what I do."

Rashie reports being "lonely and sad" most of the time, but he finds comfort in talking to the teachers and staff at the center. He often visits the center in between AIM sessions and asks if he can paint in the studio. Because of his interest, the staff has allowed this and has encouraged his love of painting. According to Rashie,

It's exciting to be a part of an art program. Ever since my real father died, I have used art to express my feelings. I draw when I am sad in order to release feelings. The AIM program has given me something to do so that I stay out of trouble.

Although Rashie sometimes uses art as a method of escape, throughout the 2 years in which he has participated, teachers have observed and he has continued to report that his outlook is bleak. His own statements suggest that the neighborhood in which he lives may be a factor in his negative mood. Of it he says, "When I draw, I feel like I am in another world. When I go home after class, I feel like I am walking 
back into hell." In interviews, Rashie explained that by "home" he means the area surrounding his house- he feels that his family is very loving but his environment is "horrible." Rashie is very concerned about the future due to his surroundings:

People are going to get shot in front of me. Everything like this happens where I live. I can see people getting shot, raped, and kidnapped. People are always getting hurt. My mom said that the world is just going to get harder. My dad isn't there any more and it makes me angry. I love my stepdad because he is good to my mom. He made a choice between staying with us and staying in a gang. My stepdad is harassed and called names by the gang. I pray for my future.

Despite his rather gloomy attitude, however, Rashie sees himself as someone who will make a change to this desolate future. He thinks that building houses for poor people is part of the answer:

I want to help people have homes to live in. I want to keep streets clean. If people had homes to live in there would not be the blankets and boxes in the streets. These people would not get hurt if they had a place to live. Art helps me to see these homes in my mind. I will build them.

Rashie has very few friends and spends the majority of his time babysitting his little sister. Noting the need to protect her from the dangerous surroundings, he brings her to the AIM art studio. Other children teased him about his relationships with his sister and mother:

When I don't understand I get frustrated. I don't like to get angry and lose my temper. I wish I had better control over my temper. I try to do the right thing. I love my mom, dad, and sister and kids make fun of me for it. People are always in my face about my family. They call me sissy, fag, or mama's boy because I hold my mama and sister's hands.

Teasing by other children has taken a toll on Rashie's ability to control his anger. Of this difficulty, he said,

If someone hits me I hit them back. Sometimes, I go tell the teacher or an adult if someone messes with me. It bothers me when people call me names. I call them names back. I think that people are jealous of me and I ignore them.

Rashie does not feel close to anyone at school and claims, "it is not important to have friends." Other children in AIM stay away from him but respect him because of his artistic talent. Rashie described himself in the following way: 
I am negative. I don't have happy thoughts about myself. Kids tease me. My mom says they are jealous because I have a good heart. I feel sad and hurt most of the time. Sometimes when I am nice to people, they use it against me. I want to be good but sometimes I have to be mean. I can't trust anyone.

After spending time in the AIM program, Rashie seemed to find outlets for his anger and appeared to gain stronger coping skills. One such outlet was art: "When I am angry I scribble, I write, draw and express my feelings." Although afraid of "gangs and bad kids," Rashie has become more secure in his objection to their temptations: "Bad kids follow you and try to get you to do drugs or buy drugs. They follow you until you give in but I refuse to let them influence me."

Rashie continues to visit the center. He has made positive relationships with the staff, and the AIM art studio offers him a safe space to escape from the dangers of his neighborhood.

\section{JONATHAN}

Jonathan is an 11-year-old African American who lives with his mom in a lower middle income Black community on the East Side. Although his mom is active in the community and is very strict with her child, his father has been in jail for the past 5 years. Jonathan harbors a great deal of anger and resentment toward his father but has a nurturing attitude toward his mother. Jonathan was a participant in a mentor program at the center and when he heard about the AIM program, he joined.

Jonathan is quiet, shy, athletic, and very interested in science. Of his physical appearance, he said,

Skinny is just the way I am. It's not good or bad, it is just the way I look. I am unique because I get good grades. Others tell me that I need to change my attitude but I don't agree. It is important to stand up for myself.

According to the teachers, Jonathan is not particularly interested in art, but he "loves drawing caricatures and super heroes." He likes the social aspect of the classes and is well liked by the other kids. Despite his shyness, he is considered a leader in the classes. He does a lot of "clowning around" in the classroom but remains very respectful of his teachers.

At home, Jonathan lives in a structured, strict environment. Of it he said,

When I get home, I change my clothes, eat and do my homework. My mom does not allow me to hang out with my friends unless she knows them and their families personally. I don't think this is fair and I wish my mom weren't so strict. I know she has to be. 
This strictness, Jonathan claimed, is one of the reasons he stays away from drugs and alcohol:

I have been tempted to use drugs and alcohol by kids that I know. They also try to get me to skip school. I have never tried these things because of my mom and my future. If someone tempts me, I go tell my mom. I am close with my mom and I talk with her about everything. I only think about my future and helping my mom.

Because the future is very important to Jonathan, he talks about it often with other children, the teachers, and the AIM staff. Of his future he said,

I see a great job as a volcanologist. I see my mom being proud. A wife, nice house, children, and a good neighborhood. I want my kids to attend the right school. I wish my school were better but my mom is doing the best she can.

As mentioned, Jonathan is well liked by other children (as evidenced by interviews with other children in the AIM program), but he is not always sure about the way others see him. Some days he has a good self-image but other days he is frustrated and feels that kids are jealous of him. He gets angry when he responds in a way that he regrets later. According to Jonathan, "I don't like my hair cut. Kids tease me. They don't like me because I have a good-looking haircut and I am tall. I think they are jealous." Jonathan initially exhibited a contradictory attitude about confrontational situations: "I tell people to mind their own business. If someone hit me I would probably hit them back. But first I would tell the teacher. I have never been in a fight." During the last interview, Jonathan's attitude was somewhat less ambiguous. When asked what he would do if another child made him angry, he responded:

I ignore others when they make me angry. I block them out and don't pay them any attention. If someone hits me I will go psycho. I won't hit them back but I start using hand gestures and saying crazy things to them. I might go and tell the principal. We are good friends. You have to be careful in school because some kids fight because of accidental contact in the halls.

Jonathan is now in high school. He is a diligent student and plans to attend college to study science.

\section{SHEILAY}

A cousin of Jonathan's, Sheilay joined AIM on his recommendation. She said that art is an important part of her life: 
Making art has always been a part of my life since I was a small child. I hope that I will learn new things like drawing techniques and mixing color. I also enjoy talking to other kids and making new friends.

Sheilay is a 12-year-old African American girl and lives with her mom and dad in the same neighborhood as her cousin Jonathan. She has a little sister and an older brother. Although she and Jonathan are good friends, they disagree a lot in class and "give each other a hard time." Sheilay acts much older than she is. She is a nurturer and spends a lot of time helping the teachers and the younger children in the program. She has a good self-image, although it is laden with outside influences on her notions of beauty:

I am smart, adventurous, nice, and sometimes I am mean. I am moody. I get very good grades in school but I can always do better. I am different in society because I am an African American female. I get mad when people think that Blacks are dumb. There are so many smart Blacks. I wish I were thinner and had longer hair. (Note: This child is not overweight)

Sheilay is a strong girl and prides herself on her ability to cope with life's problems:

Even though I have a lot of conflicts in my life, I will not use drugs. So many kids are not in school because they are dead. So many young fathers are in jail and don't get to see their kids grow up. TV says that drugs can make you feel good but that is only for a short time and then you will feel worse.

She has a positive outlook on life and says, "I am outgoing. I don't care what other people think about me. I am not foolish like some other teenagers. I try to think before I speak. My artistic talent is what I like best about myself."

Sheilay is quite open with the teachers and staff about the problems in her life. She longs to "live a middle class life with a family." She wants to "get out of the ghetto" and to "marry someone wonderful who will be nice to [her]." Sheilay is very concerned and sometimes even preoccupied with the future of Blacks, especially Black girls. Of them she says, "Black girls have problems that other people don't. They have babies because they want someone they can love that will love them in return. How can we help them?"

Sheilay has high expectations for herself and says that she wants to be a doctor and has asked the staff several times about setting up meetings with her and an African American doctor. In her words, she would like a mentor who can "show her the ropes" in the medical future. According to Sheilay, 
I would like to become a doctor that will go to the other places-poor places around the world like Africa and work there to help people. My mom is sick and cannot do a lot with us. I don't want other kids to go through this so I will be a doctor and cure everyone's mother.

Sheilay is now in high school and is enrolled in college preparatory classes. She is a volunteer with the AIM program and has encouraged other children to join AIM.

\section{DISCUSSION AND IMPLICATIONS}

From interviews with 40 children in the AIM program, we have learned much about being a child at the beginning of the 21 st century. Our purpose was to share this knowledge. We hoped to shed light on the thoughts, experiences, and realities of children living in challenging environments. As noted by John Dewey (Jackson, 1998), the process of making art can have a significant impact on learning and self-discovery. Although we are not claiming that the AIM program was the singular impetus for any changes in attitude, feelings, self-esteem, and anger control among these children, the children themselves acknowledged the significant impact in their lives due to their involvement in the program. They did not use the language of scholars and researchers, but in their own words they talked about resiliency: "I can think for myself," "I like who I am," "I refuse to let them [bad kids] influence me," "I ignore others when they make me angry," "I don't care what other people think about me." Individually and uniquely, they found ways to make wise and healthy decisions despite their exposure to risk-risks of which they are very aware.

From Jesse, Rashie, Jonathan, and Sheilay, we learn much about the difficulties that children confront and the many responsibilities that they juggle. These responsibilities range from housework, to babysitting, to caring for a sick parent: All are essential to the inner workings of their families. Despite disagreements with their parents' perspectives or dislike of the environment in which they live, they show great love and respect for the adults in their lives (Oreck et al., 1999; Otterbourg, 2000). These parental or adult relationships are crucial to the future of these children (Fiske, 1999). The relationships AIM participants had with their parents illustrate what Oreck et al. described as the vital role that parents play in the support of artistic development on the part of their children.

Lengthy discussions during interviews and observations in the classroom tell us that children crave interaction with adult mentors (Baxley, 1993; Bernard, 1992). They enjoy engaging in dialog about current events, teen issues, music, art, and their future. We need to provide more opportunities for children to discuss their concerns with adults in relaxed settings (Csikszentimihalyi \& Larson, 1984). Conversations were especially candid with artists and teachers who did not have to focus on disciplinary matters. Moreover, as Heath and Roach (1999) and Hilliard 
(personal communication, September 14, 2001) claimed, the children excelled and benefitted from the high expectations placed on them by the art teachers in the AIM program. Jesse, in particular, noticed the improvement in her artistic ability and her confidence level.

Jesse and Sheilay show us that children need to know that there are multiple definitions of beauty. Their new attitude toward beauty manifests itself in art. Many of the children discovered that talent, self-confidence, style, a sense of humor, charm, and varying skin tones and hair can all be forms of beauty, and these forms of beauty can be depicted in art. For many of the AIM children, feeling good about oneself led to a stronger sense of security and an ability to resist temptation. Many of the children also noticed that the artists did not always conform to societal expectations, that peer pressure or ridicule did not make them give up their ideas. This appreciation of individuality helped students build their self-esteem and may be one reason why a participant like Jesse, for example, began to appreciate her light, freckled Mexican skin. Whereas London (1994) focused on the student's new appreciation of beauty in his or her surroundings, we hold that making art can influence internal perceptions of beauty.

In conventional settings, like schools, there are "right" ways of doing tasks (Baxley, 1993). When making art, there are multiple ways of seeing the world, and risk taking is encouraged — be it with color mixing or the subjects of one's art. Students learn that it is permissible to fail because there are always other skills to master. For example, Rashie may be good at painting but Jonathan can make the classroom a more enjoyable place to be. Learning that there are multiple ways of accomplishing a task, demonstrating talent, and viewing the world was instrumental in developing the conflict resolution skills of the AIM students. Knowing that an issue is not always "black and white" and that they do not always have to be right, students began to avoid conflict (Rashie), ignore conflict (Jonathan, Sheilay), or use discussion as a method of approaching conflict (Jesse). Through mentoring from teachers and exposure to art and artistic methods, the children began to see problems as complex and multidimensional.

Given the environments in which these children exist, learn, and grow, the AIM program and programs like it can be the valuable link to a promising future (Witt, 1997). AIM is able to be successful because of its nexus of support in the community (Creative Partnerships for Prevention, 1998; Fiske, 1999; Heath \& Roach, 1999; Otterbourg, 2000). Regardless of the dedicated children and teachers, without funding, school and parental support, publicity, and an outlet for the artistic works of its participants, this program would not succeed. To ensure that these critical elements remain in place, programs like AIM need to create a web of interconnected support. This is essential, in the event that one source of support breaks down or is eliminated. Children count on these programs to bring them new experiences-self-discovery, problem-solving skills, opportunities for positive risk taking, and the mastery of artistic skills (Baxley, 1993; Clawson \& Coolbaugh, 2001; 
Fiske, 1999; Horowitz, 1980; London, 1994). One must ask, what would happen to a child like Rashie without an artistic outlet, and even more important, without a place to go during the summer when school is closed? Where would Rashie's time be spent if he were not visiting the art studio? When after-school programs are phased out, it can be quite damaging to a child (Fiske, 1999; Heath \& McLaughlin, 1993; Lakes, 1996; McLaughlin et al., 1994). Given the success stories presented in the literature, it is imperative that programs turn to each other for expertise and assistance rather than operating in a vacuum within their respective neighborhoods and cities. Otherwise, they will be plagued by constant funding concerns, a lack of community support, and low levels of parent involvement.

A trusting, caring relationship builds self-confidence (Fiske, 1999; Heath \& McLaughlin, 1993; Lakes, 1996; McLaughlin et al., 1994) and creates strong-willed children. These children are more likely to hold themselves in high regard and thus avoid the use of drugs and alcohol. The AIM children who felt the strongest in their refusal of temptations were those who lived rich, full lives- they played soccer or basketball, acted in school plays, read, helped out at home, and attended art class (Fiske, 1999; Heath \& McLaughlin, 1993; Lakes, 1996; McLaughlin et al., 1994). When children have diversions and special interests, they are less likely to look for negative stimuli. Such was the case for both Rashie and Jesse. For Rashie, the AIM program provided a place for him to "scribble, ... write, draw, and express [his] feelings" when he was angry. For Jesse, AIM was an outlet for her frustration with other girls. It was on the canvas that she could deal with her insecurities and fears-rather than exposing them to the girls at school.

The literature tells us that to counteract the undesirable behaviors that can take place during after-school hours, we must provide alternatives to boredom, provide opportunities for children to establish trusting relationships with adults, foster positive self-esteem, and increase resiliency. The AIM program and programs like it offer a viable alternative to the risk factors present in society. They also help children to discover their voice, their autonomy from their surrounding environment, and their own personal power. Therefore, art programs can help children to become more resilient, give them the skills to be independent, and most important, foster an ability to step outside of their personal situations and take control of their lives and their futures.

\section{ACKNOWLEDGMENTS}

Funding for this research project was provided by the Kronkosky Charitable Foundation, the San Antonio Area Foundation, and the City of San Antonio.

For his thoughtful comments on earlier drafts, we thank artist and scholar Edward Epstein. 


\section{REFERENCES}

Americans for the Arts: Institute for Community Development and in the Arts. (1998). Arts program for at-risk youth: How U.S. communities are using the arts to rescue their youth and deter crime. Washington, DC: Americans for the Arts and the National Endowment for the Arts.

Baxley, G. (1993, March). Building resiliency in youth: Imagine the difference. Paper presented at the National Conference of the Department of Health and Human Services' Substance Abuse Prevention, Washington, DC.

Becker, J. (1994). Mentoring high-risk kids. Minneapolis, MN: Johnson Institute.

Bernard, B. (1992). Fostering resiliency in kids: Protective factors in the family, school, and community. Prevention Forum, 12(3), 1-16.

Carnegie Council on Adolescent Development. (1992). A matter of time: Risk and opportunity in the non-school hours. New York: Carnegie Corporation.

Catalano, R. F., Loeber, R., \& McKinney, K. (1999). School and community interventions to prevent serious and violent offending. Juvenile Justice Bulletin, 1-12. (Report: NCJ-177624)

City of San Antonio. (2000). Annual report: 2000. San Antonio, TX: Author.

Clawson, H. J., \& Coolbaugh, K. (2001). The youth arts development project. Juvenile Justice Bulletin, 1-16. (Report: NCJ-186668)

Costello, L. (Ed.). (1995). Part of the solution: Creative alternatives for youth. Washington, DC: National Assembly of State Arts Agencies in Cooperation with the National Endowment for the Arts.

Creative Partnerships for Prevention. (1998). Using the arts and humanities to build resiliency in youth: A drug and violence prevention resource for school, cultural organizations, and others working with youth. Washington, DC: National Endowment for the Arts.

Csikszentimihalyi, M., \& Larson, R. (1984). Being adolescent. New York: Basic Books.

Denzin, N. K., \& Lincoln, Y. S. (2000). The handbook of qualitative research. Thousand Oaks, CA: Sage.

Department of Justice. (2001). FBI's National Incident-Based Reporting System. Retrieved June 17, 2001, from http://www.ojp.usdoj.gov/bjs/nibrs.htm

Dewey, J. (1934). Art as experience. New York: Capricorn Books.

Ella Austin Community Center. (1999-2000). Promotional brochure. San Antonio, TX: Author.

Fiske, E. (Ed.). (1999). Champions of change: The impact of arts on learning. Washington, DC: President's Committee on the Arts and the Humanities.

Hawkins, D., \& Catalano, R. (1993). Communities that care: Risk-focused prevention using the social development strategy. Seattle, WA: Development Research and Program, Inc.

Heath, S. B., \& McLaughlin, M. W. (1993). Identity and inner-city youth: Beyond ethnicity and gender. New York: Teachers College Press.

Heath, S. B., \& Roach, A. (1998). The arts in nonschool hours: Strategic opportunities for meeting the educational, civic learning, and job training goals of America's youth. Menlo Park, CA: Carnegie Foundation for the Advancement of Teaching.

Heath, S. B., \& Roach, A. (1999). Imaginative actuality: Learning in the arts during non-school hours. In E. Fiske (Ed.), Champions of change: The impact of arts on learning (pp. 19-34). Washington, DC: President's Committee on the Arts and the Humanities.

Horowitz, B. (1980, September). Creative photography and self expression: Groups at nineteenth ward youth project. Paper presented at the Annual Convention of the American Psychological Association, Montreal, Canada.

Jackson, P. W. (1998). John Dewey and the lessons of art. New Haven, CT: Yale University Press.

Lakes, R. D. (1996). Youth development and critical education: The promise of democratic action. Albany: State University of New York Press.

Lincoln, Y. S., \& Guba, E. G. (1985). Naturalistic inquiry. Beverly Hills, CA: Sage.

London, P. (1994). Step out-side: A community-based art education. Portsmouth, NH: Heinemann. 
McLaughlin, M., Irby, M. A., \& Langman, J. (1994). Urban sanctuaries: Lives and futures of inner-city youth. San Francisco: Jossey-Bass.

Miles, M. B., \& Huberman, A. M. (1984). Qualitative data analysis: A sourcebook for new methods. Beverly Hills, CA: Sage.

Mortimer, A. M. (1994). Consultation on afterschool programs. New York: Carnegie Council on Adolescent Development of the Carnegie Corporation of New York.

National Commission on Children. (1993). Beyond rhetoric: A new American agenda for children and families. Washington, DC: U.S. Government Printing Office.

Oreck, B., Baum, S., \& McCartney, H. (1999). Artistic talent development for urban youth: The promise and the challenge. In E. Fiske (Ed.), Champions of change: The impact of arts on learning (pp. 63-78). Washington, DC: President's Committee on the Arts and the Humanities.

Otterbourg, S. D. (2000). How the arts can enhance after-school programs. Washington, DC: National Endowment for the Arts.

Patton, M. Q. (1980). Qualitative evaluation methods. Beverly Hills, CA: Sage.

Randall, E. (1997). Art works! Prevention programs for youth and communities. Washington, DC: National Endowment for the Arts and U.S. Department of Health and Human Services, Center for Substance Abuse Prevention.

San Antonio Public Schools. (2001). Annual report: 2001. San Antonio, TX: Author.

Schorr, L. (1989). Within our reach: Breaking the cycle of disadvantage. New York: Doubleday.

Sehle, V. (1995, February 23). The art of saving kids' lives. The Chronicle of Philanthropy, p. 6.

Task Force on Youth Development and Community Programs. (1992). A matter of time: Risk and opportunity in the nonschool hours. New York: Carnegie Corporation of New York and the Carnegie Council on Adolescent Development.

Weitz, J. H. (1996). Coming up taller: Arts and humanities programs for children and youth at risk. Washington, DC: President's Committee on the Arts and Humanities.

Witt, P. (1997). Evaluation of the totally cool, totally art program. Austin, TX: Austin Parks and Recreation Department. 
APPENDIX A: "MEXICANA GIRL" BY JESSE

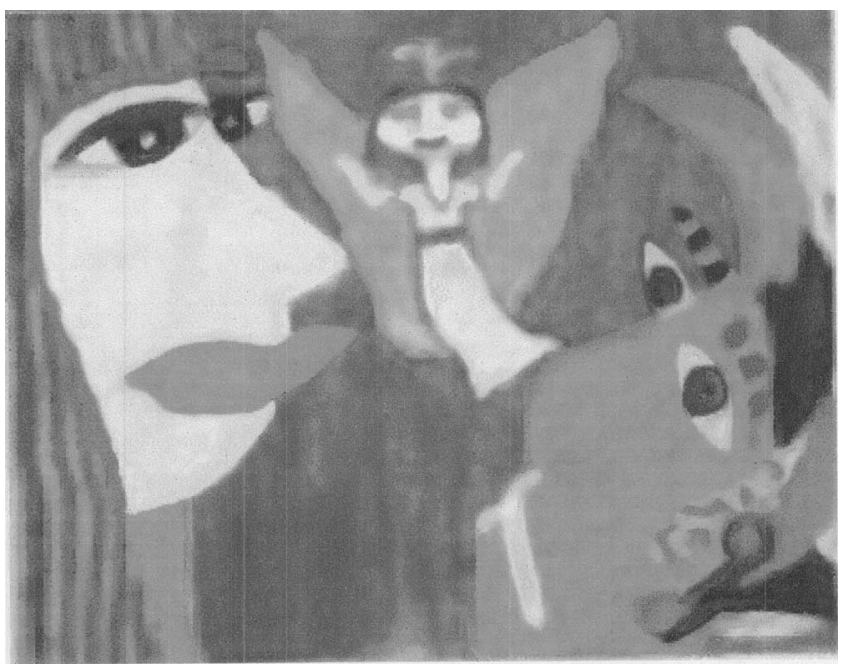

APPENDIX B: "FEAR" BY JESSE

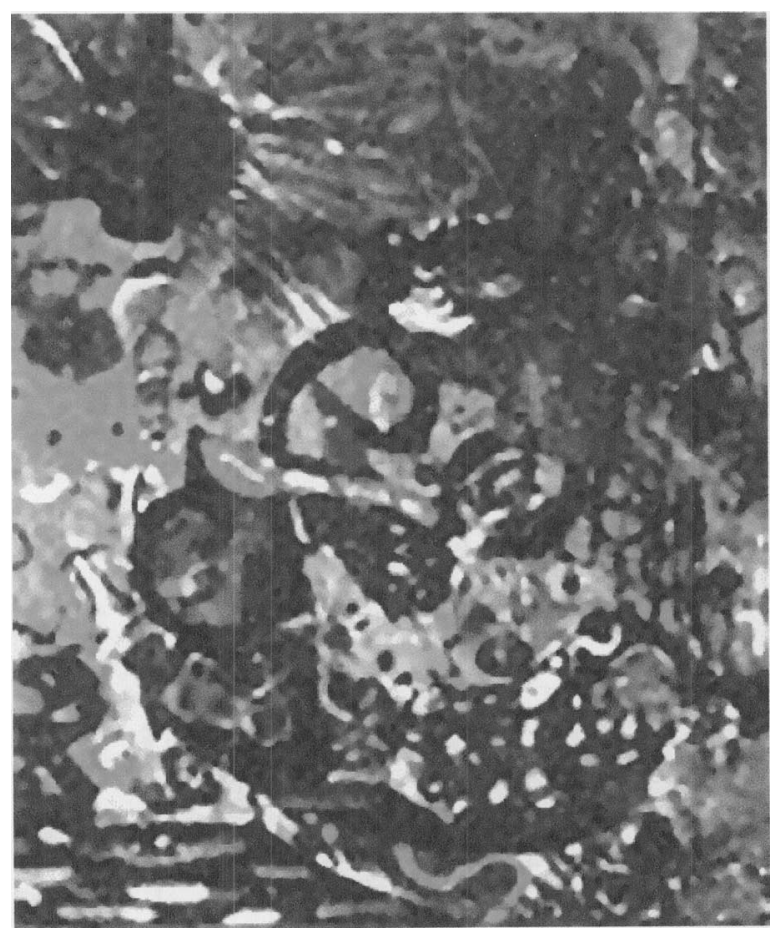


Copyright $\odot 2003$ EBSCO Publishing 